\title{
MEMAHAMI KONSEP SYARIAH, FIKIH, HUKUM DAN USHUL FIKIH
}

\section{Nurhayati}

Sekolah Tinggi Agama Islam DDI Maros || nurhayatijallo@yahoo.co.id

\begin{abstract}
Abstrak
Penelitian ini membahas tentang memahami konsep syariah, fikih, hukum, dan ushul fikih karena sekarang masyarakat sulit membedakan kata syariah, hukum, fikih dan ushul fikih,Penelitian ini dibatasi dua pokok permasalahan, yaitu: Sejauh mana pengertian dari syari'ah, fikih, hukum, dan ushul fikih bagi? dan bagaimana perbedaan antara syari'ah dengan fikih? Tujuan penelitian ini untuk membedakan arti syariah, fikih, hukum, dan ushul fikih. Jenis penelitian yang digunakan adalah hukum normatif dan pendekatan syar'i yang bercorak kepustakaan.Hasil penelitian ini menunjukkan bahwa 1) yang dimaksud dengan syariat, adalah merupakan jalan hidup muslim, ketetapan-ketetapan Allah dan ketentuan Rasul-Nya. Hukum adalah peraturan-peraturan yang mengatur tingkah laku manusia dalam suatu masyarakat, peraturan atau norma itu berupa kenyataan yang tumbuh dan berkembang dalam masyarakat. Ushul fiqh berarti asal-usul Fiqh. Fiqh ialah, suatu ilmu yang membicarakan berbagai ketentuan dan kaidah yang dapat digunakan dalam menggali dan merumuskan hukum syari'at Islam dari sumbernya. 2) Perbedaan syari'ah dengan fiqih .Syariah itu berasal dari Al-Qur'an dan As-sunah, Bersifat fundamental, Hukumnya bersifat Qath'i , Hukum Syariatnya hanya Satu ,Langsung dari Allah yang kini terdapat dalam Al-Qur'an. Sedangkan Fiqih itu karya manusia yang bisa berubah, bersifat fundamental, hukumnya dapat berubah, banyak ragam, berasal dari Ijtihad ahli hukum sebagai hasil pemahaman manusia yang dirumuskan oleh Mujtahid.
\end{abstract}

Kata Kunci: Konsep Syariah, Fikih, Hukum 


\begin{abstract}
This research discusses understanding the concept of sharia, fiqh, law and ushul fiqh because now people are difficulr to distinguish word of sharia, figh, law and ushul fiqh. This reseaarch is limited to two problem, namaly the extent of understanding of sharia, fiqh, law and ushul fiqh and how is the difference between sharia, fiqh, law and ushul figh. The purpose of this study is to distinguish themeaning of sharia, fiqh, law dan ushul fiqh. The type of research used is normative are literary. The result of this studyindicate that 1) what is meant by sharia is a muslim way of life, the provision of his apostle. Law is the rules that governhuman behavior in a sociaty, the rules or norm are in the form of a reality that grows and developes in society. Ushul figh means the original of fiqh. Formulate Islamic sharia law from its source. 2) the different between sharia and fiqh. Sharia comes from the Al-qur'an and as sunah, is fundamental, the law is fixed, the shari'a law is only one, directly from Allah which is now contained in the Al-qur'an while fiqh is a human work that can change, it is fundamental, the law can change, many kinds, derived from ijtihad legal expert as a result oh human understanding formulated by mujtahid.
\end{abstract}

Key Word : Concept Sharia, Law, Fiqh

\section{PENDAHULUAN}

$\mathrm{T}$

ak dapat dipungkiri bahwa hukum memegang peranan kunci dalam menciptakan keseimbangan tatanan dalam segala hal, baik kepastianya dlam sebuah negara atau dalam skala global yang menyangkut hukum internasional. Pada dasarnya, hakkat hukum merupakan ini peradaban suatu bangsa dalam arti yang paling murni dan mencerminkan jiwa bangsa secara lebih jelas dari lembaga apapun. Hal ini, dapat dilihat terjadinya kekacauan di berbagai belahan dunia lebih diebabkan oleh tatanan dan institusi-institusi hukum yang tidaka mapan dan masih terlalu besaar dominan dan monopooli kepentingan politik. (A.S. Diamon, 1949:.303)

Bagi umat Islam syari'ah adalah" tugas umat manusia secara menyeluruh" meliputi moral, teologi, etika pembinaan umat, aspirasi spiritual, ibadah formal dan ritual yang rinci. Syari'ah mencakup seluruh aspek hukum publik dan perorangan, kesehatan bahkan kesopanan dan pembinaan budi. (Fazlur Rahman, 1979:101). Mengingat syari'ah merupakan pedoman dalam hubungannya dengan Allah, sesama, dan lingkungan hidupnya. Mahmud Syaltut bahwa syari'at adalah hukum Allah atau peraturan yang diturunkan oleh Allah kepada manusia untuk 
dijadikan pedoman dalam secara subyektif ditentukan oleh orang hubungannya secara tiiga dimensi. yang bersangkutan ( Nu'man Al(Lihat Mahmud Syaltut, 1996: 12)

Dengan demikian, syari'ah kebenaran politik dan sosiologis dalam merupakan hukum integral yang aktualisasi syari'ah ke dalam dunia meliputi aspek vertikal dalam praktis, namun demikian sosio-kultural kaitannya dengan Tuhan, dan aspek tidak dapat diabaikan.

horizontal yang berkenaan denga

Begitu elen vitalnya hukum umat sesama dan lingkungan. H.A.R. Gibb Islam sebagai manifestasi paling tipikal menyatakan bahwa syari'ah adalah dan kongkrit dari Islam sebagai sebuah hukum Allah yang paling efektif untuk agama. Suatu hal yang mustahil untuk membentuk tatanan sosial dari segala memahami Islam tanpa memahami macam gejolak politik (H.A.R. Gibb, Muhammadanism, 1953: 11)

Syari'ah yang telah menjadi system doktrin yang independen, akan menimbulkan perpecahan atau konflik antara pemegang kekuasaan dengan para ulama, jika syari'ah terabaikan dalam suatu negara (Lihat Noel J. Coulson, A 1964: 105-106) Hal ini karena syari'ah secara teoritik berhak penuh terhadap hak-hak sipil dan politik (Majid Kharuddin, 1954: 162). Bagi umat Islam, telah menjadi kepercayaan yang mendalam bahwa otoritas kedaulatan tertinggi terletak di tangan Allah. (H.A.R.Gibb, 1953:39)

Dengan demikian, keimanan pada Islam secara obyektif ditentukan oleh pemegang kewenangan, bahkan hukumnya. Namun,, patut disadari bahwa Islam yang tertuang dalam alQur'an dan hadis sebagai standar hukum bersifat akomodatif terhadap dinamika sosio-kultural yang ada. Semangat legislasi antara Nabi dan alQur'an di satu pihak, dan dengan perkembangan yang ada pemperlihatkan arah yang jelas menuju realisasi progresif dari nilai-nilai fundamental tersebut ke dalam semangat legislasi baru, karena legislasi aktual dari al-Qur'an dan hadis sebagian telah menerima kondisi sosial yang ada sebagai batasan rujukan (Falzur Rahman :53)

Di Indonesia hukum Islam didefinisikan sebagai terjemahan dari al-fiqh al-islamy atau dlam konteks 
tertentu sebagai terjemahan dari al- hukum Islam dan telah dijadikan syari'at al-Islamiyah (A. Rafiq, rujukan utama mereka dalam 1995:3) Dalam perkembangan pengambilan keputusan hukum. selanjutnya lebih diasosiasikan sebagai Padahal kalau disadari bahwa kitabfiqh, tetapi realisasinya sebagai kitab fiqh, lima atau enam abad yang interpretasi dari syari'ah dan fiqh lalulebih merupakan ekspresi kultur sekaligus. Pada awalnya fiqh syari'ah tertentu ditempat para penyusunnya lebih mendominasi masyarakat Islam tinggal.

Indonesia. Pada hakekatnya, hukum

Dari urain latar belakang di atas Islam di Indonesia lahir dari asimilsi antara hukum Islam normatif dengan maka, dapat dipecahkan menjadi beberapa masalah yang akan dibahas muatan-muatan lokan keindonesiaan. Ia dalam makalah ini yakni 1) sejauh merupakan salah satu hukum adat. mana pengertian dari syari'ah, fikih, Palng tidak ada empat jenis pproduk hukum Islam yang telah berkembang, dan berlaku di Indonesia, yaitu fiqh, fatwa ulama, keputusan pengadilan dan perundang-undangan (A.Rafiq :25)

Fenomena umum dikalangan umat Islam memandang fiqh sebagai ekspresi kesatuan hukum Islam yang universal daripada sebagai ekspresi keragaman partikuler. Fiqh telah mewakili hukum dalam bentu cita-cita daripada sebagai respon atau refleksi kenyataan yang ada secara realis, fiqh juga memilih stabilitas daripada perubahan. Demikian halnya yang terjadi diIndonesia para ulama fiqh dalam memandang kitab-kitab fiqh klasik telah diidentikkan dengan hukum, dan ushul fikih? 2) Bagaimana perbedaan antara syari'ah dengan fikih?

\section{METODE PENELITIAN}

Jenis penelitian yang digunakan tesis ini adalah pendekatan penelitian hukum normatif atau doktrinal dan pendekatan syar'i yang bercorak kepustakaan (library research).

\section{PEMBAHASAN}

\section{Syari'ah}

Syariah adalah kata Syari'ah berasal dari kata syara'a. Kata ini menurut ar-Razi dalam bukunya Mukhtar-us Shihab bisa berarti nahaja (menempuh), awdhaha (menjelaskan) 
dan bayyan-al masalik (menunjukkan jalan). Sedangkan menurut Al-Jurjani Syari'ah bisa juga artinya mazhab dan thriqah mustaqim / jalan yang lurus. Jadi arti kata Syariah secara bahasa banyak artinya. Ungkapan Syari'ah Islamiyyah yang kita bicarakan maksudnya bukanlah semua arti secara bahasa itu.

Kata syari'ah juga seperti itu, para ulama akhirnya menggunakan istilah Syari'ah dengan arti selain arti bahasanya lalu mentradisi. Maka setiap disebut kata Syari'ah langsung dipahami dengan artinya secara tradisi itu. Imam al-Qurthubi menyebut bahwa Syari'ah artinya adalah agama yang ditetapkan oleh Allah swt.untuk hamba-hambaNya yang terdiri dari berbagai hukum dan ketentuan. Hukum dan ketentuan Allah itu disebut syariat karena memiliki kesamaan dengan sumber air minum yang menjadi sumber kehidupan bagi makhluk hidup. Makanya menurut ibn-ul Manzhur syariat itu artinya sama dengan agama.

Yang dimaksud dengan syariat atau ditulis dengan syari'"ah, secara harfiah adalah jalan ke sumber (mata) air yakni jalan lurus yang harus diikuti oleh setiap muslim,syariat merupakan jalan hidup muslim, ketetapanketetapan Allah dan ketentuan RasulNya, baik berupa larangan maupun berupa suruhan, meliputi seluruh aspek hidup dan kehidupan manusia (Ali, Mohammad Daud, 2011:.46).

Dilihat dari segi ilmu hukum, syari'at merupakan norma hukum dasar yang ditetapkan Allah, yang wajib diikuti oleh orang Islam bedasarkan iman yang berkaitan dengan akhlak, baik dlam hubungannya denganAllah maupun dengan sesama manusia dan benda dalam masyarakat. Nrma hukum dasar ini dijelaskan dan atau dirinci lebih lanjut oleh Nabi Muhammad saw. sebagai Rasul-Nya. Karena itu, syari'at terdapat di dalam al-Qur'an dan di dalam kitab-kitab Hadis.

\section{Fikih}

Fikih adalah di alam bahasa Arab, perkataan figh yang ditulis fiqih atau kadang-kadang fekih setelah diindonesiakan, artinya paham atau pengertian. Kalau dihubungakan dengan ilmu ,dalam hubungan ini dapat juga dirumuskan (dengan kata lain), ilmu fiqih adalah ilmu yang bertugas mnentukan dan menguraikan norma-norma hukum dasar yang terdapat di dalam al-Qur'an dan 
ketentuan-ketentuan umum yang praktis ('amaliyyah) yang digali dari terdapat dalam Sunnah Nabi yang dalil-dalil yang bersifat rinci (tafshîlî) . direkam dalm kitab-kitab hadis.

Fikih adalah pengetahuan yang

Dengan kata lain ilmu fikiih dihasilkan dari sejumlah hukum syariat adalah ilmu yang berusaha memahami yang bersifat cabang yang digunakan hukum-hukum yang terdapat di dalam al-Qur'an dan sunnah Nabi Muhammad sebagai landasan untuk masalah amal perbuatan dan bukan digunakan untuk diterapkan pada perbuatan manusia yang telah dewasa yang sehat akalnya yang berkewajiban landasan dalam masalah akidah .

\section{Hukum}

Hukum adalah jika berbicara melaksanakan hukum Islam. Hasil pemahaman tentang hukum Islam itu disusun secara sistematis dalam kitabkitab fiqih dan disbut hukum fiqih. Contoh hukum fiqih Islam yang ditulis dalam bahasa Indonesia oleh orang Indonesia adalah, misalnya, fiqih Islam karya H.Sulaiman Rasjid yang sejak diterbitkan pertama kali tahun 1954 sampai kini (1998) telah puluhan kali dicetak ulang.

Al-Ghazali berpendapat bahwa secara literal, fikih (fiqh) bermakna al'ilm wa al-fahm (ilmu dan pemahaman). Sedangkan menurut Taqiyyuddin al-Nabhani, secara literal, fikih bermakna pemahaman (al-fahm) . Sementara itu, secara istilah, para ulama mendefinisikan fikih sebagai berikut: Fikih adalah pengetahuan tentang hukum syariat yang bersifat tentang hukum,secara sederhana segera terlintas dalam pikiran kita peraturanperaturan atau seperangkat norma yang mengatur tingkah laku manusia dalam suatu masyarakat, baik peraturan atau norma itu berupa kenyataan yang tumbuh dan berkembang dalam masyarakat maupun peraturan atau norma yang dibuat dengan cara tertentu dan ditegakkan oleh penguasa. Bentuknya mungkin berupa hukum yang tidak tertulis seperti hukum adat, mungkin juga berupa hukum tertulis dalam peraturan perundang-undangan seperti hukum barat. Hukum Barat melalui asas konkordansi, sejak pertengahan abad ke-19(1855) berlaku di Indonesia. Hukum dalam konsepsi seperti hukum Barat adalah hukum yang sengaja dibuat oleh manusia untuk mengatur kepentingan manusia 


\section{J-HES}

Hukum Ekonomi Syariah

Volume 2, No. 2, Juli-Desember 2018 | p-ISSN: 2549-4872 | e-ISSN: 2654-4970

sendiri dalam masyarakat tertentu. Menurut Istitah yang digunakan oleh Dalam konssepsi hukum perundang- para ahli Ushul Fikih ini, Ushul Fikih undangan (barat), yang diatur hkum itu ialah, suatu ilmu yang hanyalah hubunan manusia dengan membicarakan berbagai ketentuan dan manusia lain dan benda dalam kaidah yang dapat digunakan dalam masyarakat.

Disamping itu, ada konsepsi hukum lain, di antaranya adalah konsepsi hukum Islam. Dasar dan kerangka hukumnya ditetapkan oleh Allah, tidak hanya mengatur hubungan manusia dengan manusia lain dan benda dalam masyarakat, tetapi juga hubungan-hubungan lainnya, karena manusia yang hidup dalam masyarakat itu mempunyai berbagai hubungan. Hubungan-hubungan itu, seperti hubungan manusia dengan Tuhan, hubungan manusia dengan manusia lain dan hubungan manusia dengan benda dalamm masyarakat serta alam sekitarnya. Interaksi manusia dalam berbagai tata hubungan itu diatur oleh seperangkat ukurann tingkah laku yang di dalam bahasa Arab, disebut hukm jamaknya ahkam.

\section{Ushul fikih.}

Ushul fikih adalah Menurut aslinya kata "Ushul Fikih" adalah kata yang berasal dari bahasa Arab "Ushulul menggali dan merumuskan hukum syari'at Islam dari sumbernya. Dalam pemakaiannya, kadang-kadang ilmu ini digunakan untuk menetapkan dalil bagi sesuatu hukum; kadang-kadang untuk menetapkan hukum dengan mempergunakan dalil Ayat-ayat AlOur'an dan Sunnah Rasul yang berhubungan dengan perbuatan mukallaf, dirumuskan berbentuk "hukum Fiqh" (ilmu Fikih) supaya dapat diamalkan dengan mudah. Demikian pula peristiwa yang terjadi atau sesuatu yang ditemukan dalam kehidupan dapat ditentukan hukum atau statusnya dengan mempergunakan dalil. Dengan kata lain ushul fiqih adalah Kumpulan kaidah-kaidah yang menjelaskan kepada faqih (ahli hukum Islam) cara-cara mengeluarkan hukumhukum dari dalil-dalil syara'.

Yang menjadi obyek utama dalam pembahasan Ushul Fikih ialah Adillah Syar'iyah (dalil-dalil syar'i) yang merupakan sumber hukum dalam Fikih" yang berarti asal-usul Fiqh. ajaran Islam. Selain dari membicarakan 
pengertian dan kedudukannya dalam hukum Adillah Syar'iyah itu dilengkapi dengan berbagai ketentuan dalam merumuskan hukum dengan mempergunakan masing-masing dalil itu.

Topik-topik dan ruang lingkup yang dibicarakan dalam pembahasan ilmu Ushul Fikih ini meliputi:

a. Bentuk-bentuk dan macam-macam hukum, seperti hukum taklifi (wajib, sunnat, mubah, makruh, haram) dan hukum wadl'i (sabab, syarat, mani', 'illat, shah, batal, azimah dan rukhshah).

b. Masalah perbuatan seseorang yang akan dikenal hukum (mahkum fihi) seperti apakah perbuatan itu sengaja atau tidak, dalam kemampuannya atau tidak, menyangkut hubungan dengan manusia atau Tuhan, apa dengan kemauan sendiri atau dipaksa, dan sebagainya.

c. Pelaku suatu perbuatan yang akan dikenai hukum (mahkum 'alaihi) apakah pelaku itu mukallaf atau tidak, apa sudah cukup syarat taklif padanya atau tidak, apakah orang itu ahliyah atau bukan, dan sebagainya. d. Keadaan atau sesuatu yang menghalangi berlakunya hukum ini meliputi keadaan yang disebabkan oleh usaha manusia, keadaan yang sudah terjadi tanpa usaha manusia yang pertama disebut awarid muktasabah, yang kedua disebut awarid samawiyah.

e. Masalah istinbath dan istidlal meliputi makna zhahir nash, takwil dalalah lafazh, mantuq dan mafhum yang beraneka ragam, 'am dan khas, muthlaq dan muqayyad, nasikh dan mansukh, dan sebagainya.

f. Masalah ra'yu, ijtihad, ittiba' dan taqlid; meliputi kedudukan rakyu dan batas-batas penggunannya, fungsi dan kedudukan ijtihad, syarat-syarat mujtahid, bahaya taqlid dan sebagainya.

g. Masalah adillah syar'iyah, yang meliputi pembahasan Al-Qur'an, As-Sunnah, ijma', qiyas, istihsan, istishlah, istishhab, mazhabus shahabi, al-'urf, syar'u man qablana, bara'atul ashliyah, sadduz zari'ah, maqashidus syari'ah/ususus syari'ah.

h. Masa'ah rakyu dan qiyas; meliputi. ashal, far'u, illat, masalikul illat, al- 
washful munasib, as-sabru wat taqsim, tanqihul manath, ad-dauran, as-syabhu, ilghaul fariq; dan selanjutnya dibicarakan masalah ta'arudl wat tarjih dengan berbagai bentuk dan penyelesaiannya.

Perbedaan antara syari'ah dengan fikih

Pada pokoknya perbedaan antara keduanya adalah sebagi berrikut:

1. Syariat, seperti telah disinggung dalam uraian erdahulu terdapat di daalam al-Qur'an dan kitab-kitab hadis. Kalau kita berbucara tentang syariat, yang dimaksud adalah wahyu Allah dan sunnahh Nabi Muhammad sebagi RasulNya.sedangkan apabila kita berbicara tetang fikih, yang dimaksud adalah pemahaman manusia yang memenuhi syarat tentang syariar dan hasil pemahaman itu.

2. Syariat bersifat fundamental dan mempunyai ruang lingkup yang lebih luas karena ke dalamnya, oleh banyak ahli, dimasukkan juga akidah dan akhlak. Sedangkan fikih bersifat instrumental, ruamg lingkupnya terbatas pada hukum yang mengatur perbuatan manusia, yang biasanya disebut sebagai perbuatan hukum.

3. Syariat adalah ketetapan Allah dan ketentuan Rasul-Nya, karena itu berlaku abadi sedangkan fikih adalah karya manusia yang tidak berlaku abadi, dapat berubah dari masa ke masa.

4. Syariat hanya satu, sedangkam fikih mungkin lebih dari satu seperti (misalnya) terlihat pada aliran-aliran hukum yang disebut dengan istilah mazahib atau mazhab-mazhab itu.

5. Syariat menunjukkan kesatuan dalam Islam, sedangkan fikih menujukkan keragamannya.

\section{KESIMPULAN}

Berdasarkan penjelas di atas maka dapat ditari kesimpulan bahwa:

1. a. Yang dimaksud dengan syariat atau ditulis dengan syari"'ah, secara harfiah adalah jalan ke sumber (mata) air yakni jalan lurus yang harus diikuti oleh setiap muslim, syariat merupakan jalan hidup muslim, ketetapan-ketetapan Allah dan ketentuan Rasul-Nya, baik berupa larangan maupun berupa suruhan, meliputi seluruh 
aspek hidup dan kehidupan manusia.

b. fiqih adalah ilmu yang bertugas mnentukan dan menguraikan norma-norma hukum dasar yang terdapat di dalam al-Qur'an dan ketentuan-ketentuan umum yang terdapat dalam Sunnah Nabi yang direkam dalm kitab-kitab hadis.

c. Hukum adalah peraturanperaturan atau seperangkat norma yang mengatur tingkah laku manusia dalam suatu masyarakat, baik peraturan atau norma itu berupa kenyataan yang tumbuh dan berkembang dalam masyarakat maupun peraturan atau norma yang dibuat dengan cara tertentu dan ditegakkan oleh penguasa.

d. Ushul fiqh adalah Menurut aslinya kata "Ushul Fiqh" adalah kata yang berasal dari bahasa Arab "Ushulul Fiqh" yang berarti asal-usul Fiqh. Menurut Istitah yang digunakan oleh para ahli Ushul Fiqh ini, Ushul Fiqh itu ialah, suatu ilmu yang membicarakan berbagai ketentuan dan kaidah yang dapat digunakan dalam menggali dan merumuskan hukum syari'at Islam dari sumbernya.

2. Perbedaan antara syari'ah dengan fiqih

a. Syariah

1) Berasal dari Al-Qur'an dan As-sunah

2) Bersifat fundamental

3) Hukumnta bersifat Qath'i (tidak berubah)

4) Hukum Syariatnya hanya Satu (Universal)

5) Langsung dari Allah yang kini terdapat dalam AlQur'an

b. Fiqih

1) Karya Manusia yang bisa Berubah

2) Bersifat Fundamental

3) Hukumnya dapat berubah

4) Banyak berbagai ragam

Bersal dari Ijtihad para ahli hukum sebagai hasil pemahaman manusia yang dirumuskan oleh Mujtahid 


\section{J-HES}

Hukum Ekonomi Syariah

Volume 2, No. 2, Juli-Desember 2018 | p-ISSN: 2549-4872 | e-ISSN: 2654-4970

\section{DAFTAR PUSTAKA}

Abdurrauf. al-Qur'an dan Ilmu Hukum. Jakarat; Bulan Bintang, 1970.

Abu Zahra, al-Imam. Ushul al-Fiqhi. al-Qahirah: Dar al Fikr al- Arabi: 2006.

Ali, Mohammad Daud.. Hukum Islam, Pengantar Ilmu Hukum dan Tata Hukum Islam din Indonesia. Cet. XVI; Jakarta: PT.Rajagrafindo Persada, 2011.

Azzam, Abdul Aziz Muhammad. al-Qawaid al-Fiqhiyyah. al-Qahirah: Dar alHadits, 2005.

Bak, Ahmad Ibrahim. Ilmu Ushul al-Fiqh wa Yalihi Tarikh al-Tasyri al-Islami alQahirah:Dar al-Ansahar, 1862.

Cahyani, Intan. Problematika Penerapan Produk Pemikiran Hukum Islam Sebelum dan Sesudah Lahirnya UU Nomor 7 Tahun 1989, (Alauddin University Press), 2011.

Coulson, Noel . Hukum Islam dalam Perspektif Sejarah. Jakarta: P3M, 1987.

Hanafi, A. Pengantar dan Sejarah Hukum Islam. Jakarta: Bulan Bintang, 1970. 